\title{
凍結乾燥胼原繊維タンパク質の変性に及ぼすスクロースの影響

\author{
松田由美子
} \\ (1978 年 11 月 29 日受理)
}

Influence of Sucrose on the Protein Denaturation of Lyophilized

Carp Myofibrils during Storage

\section{Yumiko MATSUDA*1}

The effect of various concentrations of sucrose on the quality change of lyophilized myofibrils during storage was examined. Myofibrils from live carp, Cyprinus carpio, were ground with polyphosphates and sucrose. The mixtures were freeze-dried at $35^{\circ} \mathrm{C}$, ground into powder, packed in $0.1 \mathrm{~mm}$ thick polyethylene bags, and stored for 6 months at $20^{\circ} \mathrm{C}$. At suitable intervals, aliquots of the mixtures were taken out and examined as to quality, using as indexes the solubility in $0.6 \mathrm{M} \mathrm{KCl}$, the relative viscosity, and the ATPase activity of the $0.6 \mathrm{M} \mathrm{KCl}$ extractable prolein, and the total ATPase activity.

The higher the concentration of sucrose, the better wa; the quality retention of the powder. Above 5 per cent in a wet basis before freeze-drying, however, there was no significant difference in the effect of sucrose. It was also noted that protein denaturation was accelerated in the powder to which but polyphosphates had been added.

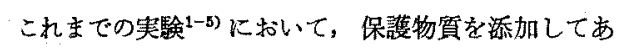
るスケトゥダラ洽涷すり身を凍結乾蛅するとかまぼこ形 成能を保持している魚粉が得られること，ならびにその 後の狩蔵中下执いても適当な条件下に監くことにより， がに゚形成能を長く保持しらることを明らかにしてき た。本実験に拈いて，更に，このようなかれぼこ形成能 のある魚粉の製造と貯蔵に関する基礎的研究を行うこと とし、コイの筋原瀻維を用いて魚肉タンパク質に対する スクロースの保護效果を検討した。

保護効果の判定は $0.6 \mathrm{M} \mathrm{KCl}$ 可溶珄等素量, 粘度,な らびに ATPase 活性を剆定することにより行うことと した。可溶性空素量はかまばこ形成能の指標とは必ずし むなり得ないことがすで示唆されているが，かまば こ形成能の指褾となりうる湘定法はいまだに見出されて いない。高次構造を持つタンパク質の性質を一つの測定 結果から諭ずるのは危険とされていることから，三つの

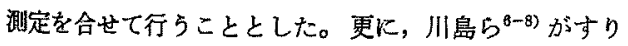
身のかまぼこ形成能は比活性と溶解量を勘案したところ の全 ATPase 活性と最わ相関が高く，10 g のすり身中 の全 ATPase 活珄の表示を提唱しているが，本実験で もこれに類似した表示を行い，總合的に保護効果を判定 することとした。 冷涷すり身の添加糖量は無塩すり身では陸上 $5 \%$, 洋
上 $8 \%$ ，加塩すり身で陸上，洋上としに $10 \%$ に規格 化されている。なお，無塩と，最近で经陸上加馧すり身 にもポリリン酸塩が $0.2 \%$ 添加されている。本实験では コイ筋原䄉維にポリリン酸塩 $0.2 \%$ とスクロース $10 \%$ 以下を添加し, 凍結乾燥後, 貯藏中にむけるスク一ロス のタンパク質保護奻果と至適濃度を検討した。

\section{実 験 方 法}

材料 市販のコイ, Cyprinus carpio の活魚, 体長 30 $\mathrm{cm}$, 重量約 $1 \mathrm{~kg}$ を供試した。

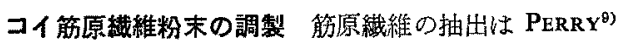
原法の簡易法*2によつた。コイ活魚を延䯣即殺し, 流水 で划口を洗いながら十分脱血後，断頭した。三枚に卸 し，普通肉のみを取り出し，ポりェチレン袋に入れ，外 側から水水で彾却した。筋肉をチョッパーにが，10倍 量の $0.12 \mathrm{M} \mathrm{KCl}$ 溶液索加克, 泡止めブレンダー（回転 数 7,000 rpm) で 30 秒間ずつ2 回絸砕し，15 デニー ルのナイロン布で沪過して結合組蟣を除去後, 沪液を $5,000 \times \mathrm{g}$ で運続冷却遠心分離した。得られた沈熉を再 度同じ操作により洗浄し，遠心分離し，筋原瀻維試料を 得た。本試料の水分，粗タンパク質はそれぞれ 89.6, $8.6 \%$ であつた。

本試料にポリリン酸塩（ピロリン酸ナトリウムとトリ

*1 東京水産大学 (Tokyo University of Fisheries, 5-7, Konan 4, Minato-ku, Tokyo 108).

*2 野口敏・松本重一郎：禾発表 


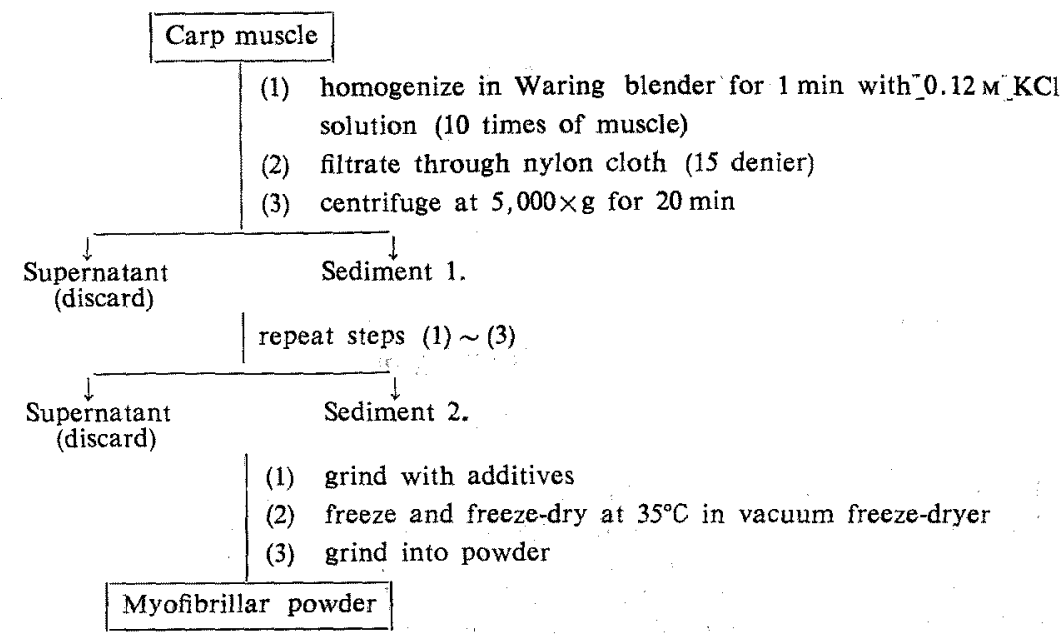

Fig. 1. Preparation of lyophilized myofibrillar powder from carp muscle.

ポリリン酸ナトリウムを等量混合したもの；PP) $0.2 \%$ とスタロースを $0 ， 1 ， 3 ， 5 ， 8 ， 10 \%$ の割合で添加混合 し, 真空凍結後, 板温度 $35^{\circ} \mathrm{C}$ で 15 洔間乾燥した。そ の間品温は $-42 \sim+25^{\circ} \mathrm{C}$ であつた。㛺學終了の判定は 次の方法によつた。つまり試料温度の上昇, ピラニー真 空計の変䡃, コールドトラップ温度の降下がほとんどな くなつて活活一定值を保つようになつた時，全てのバル ブを閉じ，一定時間のピラニー真空計の指針の変動を测 定するこを何回か絽返し，変動が小さくなつた時をる つて行つた。乾喿徯はただらに乳鉢で粉砕して，コイ筋 原䋘維粉末を得た。操作法の概要を Fig. 1 に示す。

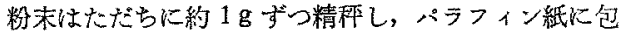
み，厚さ $0.1 \mathrm{~mm}$ のポリエチレン袋に真空包装し， $20^{\circ} \mathrm{C}$ に野藏した。また，無添加の筋原瀻維を同様に処理して 対照亡した。

品啠判定 凍絽乾燥直後之眝蔵中に一部を取り出し， 次の湘定方法により品質を判定した。

1. 可溶性窒素量：試料約 $1 \mathrm{~g}$ に $5^{\circ} \mathrm{C}$ K予冷した 0.6 $\mathrm{M} \mathrm{KCl}$ 溶液 (WEBER-EDSALL 溶液, pH 7,3) $50 \mathrm{ml}$ を加光，真空容器中で真空度 50 Torr に約 5 分間保も， $5^{\circ} \mathrm{C}$ に 1 時間放置した後 $0.6 \mathrm{M} \mathrm{KCl}$ 学加えて総量を 200 $\mathrm{ml}$ とし, 泡止めブレンダー（回転数 $2,000 \mathrm{rpm}$ ) で 30 秒間ざつ 2 回細碎し， $5,000 \times \mathrm{g} て 20$ 分間泠却遠心分 離した。上澄夜中の窒素量をミクロケルダール法で溳定

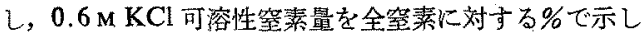
$7=0$

2. 粘度： $0.6 \mathrm{M} \mathrm{KCl}$ 可溶性タンパク質の溶液を筒宜

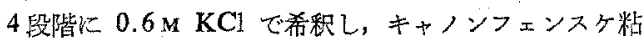
度計 No. 50 , 動粘度係数 0.005 前後のものを用い, それ ぞれの粘度を $25^{\circ} \mathrm{C}$ で测定し，タンパク質㳻度 $2 \mathrm{mg} / \mathrm{ml}$
における相対粘度を補間法に上り求めた。

3. ATPase 活性: NoGUCHI 5 $^{10)}$ の方法に従つた。 $0.6 \mathrm{M} \mathrm{KCl}$ 可溶性タンパク質の溶液 $1 \mathrm{~m} l$ を $25 \mathrm{ml}$ 容

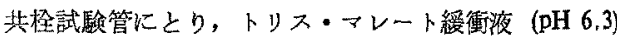
$1 \mathrm{~m} l, 1,7 \mathrm{M} \mathrm{KCl}(0.6 \mathrm{M} \mathrm{KCl}$ と同様に娚製したもの) $1.6 \mathrm{ml}, 10 \mathrm{mM} \mathrm{CaCl} l_{2} 0.4 \mathrm{ml}$ を順次混合後, $25^{\circ} \mathrm{C} \mathrm{K}$ 10 分間保ち，それに $6.6 \mathrm{~mm} \mathrm{ATP} 2.0 \mathrm{ml}$ を加克て $1 ， 2 ， 3$ 分間反応させ，10\% TCA $\left(0^{\circ} \mathrm{C}\right) 5 \mathrm{ml}$ を加

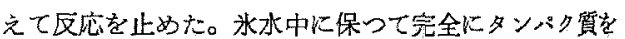
沈尉させた後，東洋滤紙 No. 7 で汇過し，洰液中の無 機りンを FISKE-SUBBAROW ${ }^{11)}$ 原法の改良法 ${ }^{12,18)}$ ( り娜定した。この反充系の最終濃度はTable 1 に示 ごとくである。

ATPase 活性はタンパタ筫 $1 \mathrm{mg}$ 当り 1 分間比生咸す る無機りンの $\mu \mathrm{mol}$ 濃度で洨示した。

4. 全 ATPase 活性：かまぼこ形成能は溶出タンパ ク質の比活性と溶解量とのかかわりあいで決まると考兄 られるところから，可溶性窒素量に ATPase 比活性老乗 じたもの，つ票り，試料綵タンパク質 $1 \mathrm{mg}$ 当り1分間 に生成する無機リンの $\mu \mathrm{mol}$ 濃度でそれを素示した。

\section{結果}

可溶性空素量 Fig. 2 に示すごとく，乾熶直後にスク

Table 1. Reaction mixture of ATPase activity

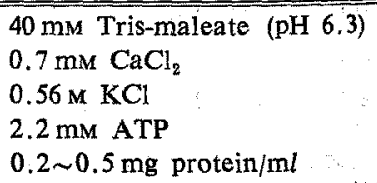

The reaction was carried out for $1-3$ min at $25^{\circ} \mathrm{C}$. 


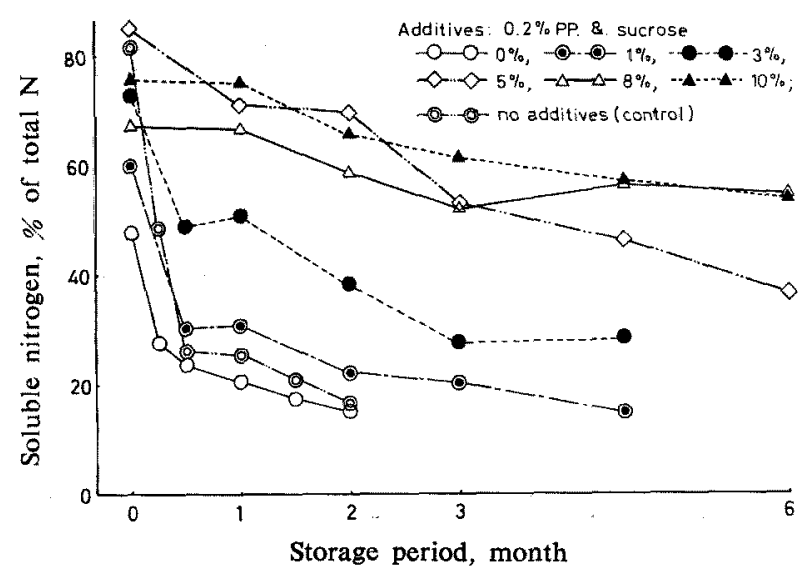

Fig. 2. Effect of sucrose of various concentrations on the changes in soluble nitrogen content of lyophilized carp myofibrillar powder during storage at $20^{\circ} \mathrm{C}$.

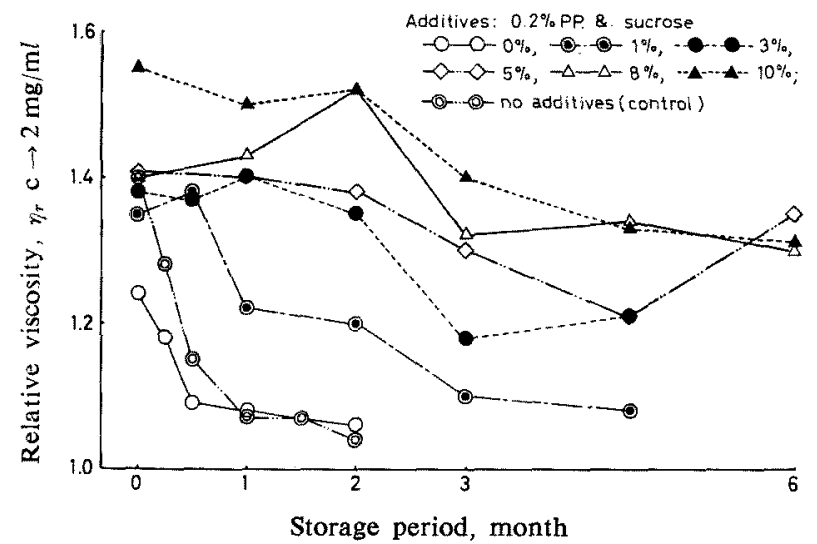

Fig. 3. Effect of sucrose of various concentrations on the changes in relative viscosity of $0.6 \mathrm{M} \mathrm{KCl}$ soluble protein in lyophilized carp myofibrillar powder during storage at $20^{\circ} \mathrm{C}$.

ロース濃度による相違が認められた。0.2\% PP だけ添 加したものでは值が低く，しかも眝蔵 $1 / 4$ 力月後に激减 した。この低下は対照よりも大きく，PP たけの添加で 榀讙効果を示さず，むしろ変性促進の傾向が示され た。一方，スクロース濃度を增すと低下が抑えられた が, 8\% と 10\% 添加したものでは大差は認められなか otso

粘度 Fig. 3 に示すごとく，0.2\% PP だけ洿加した ものては大きく低下した。一方，スクロース添加は低濃 度で保護效果を示し，濃度が增すと低下が排えられ た。ただし，6力月䠉蔵後には5〜10\% 添加したもので は相连がみられなかつた。

ATPase 活性 Fig. 4 に示すごとく, 0.2\% PPだけ
添加したものではむしる峦性促進が認められた。スクロ 一ス添加により保護效果が現れ，濃度が增すにつれて活 性の低下が抑兄られた。4.5〜6力月眝藏後には 5〜10\% 添加したものでは相逵がみられなかつた。

全 ATPase 活性 Fig. 5 K示すごとく， $0.2 \%$ PP だけ添加したものでは対照上り低く, 明らが变性促進

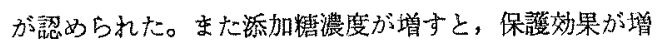
すことが惩められた。

$$
\text { 考察 }
$$

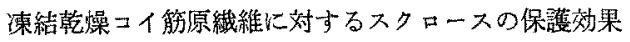
は $10 \%$ 以下の添加では湦度が增すほど大きいこと，し かし，5\%以上で差が小さいことが認められた。 


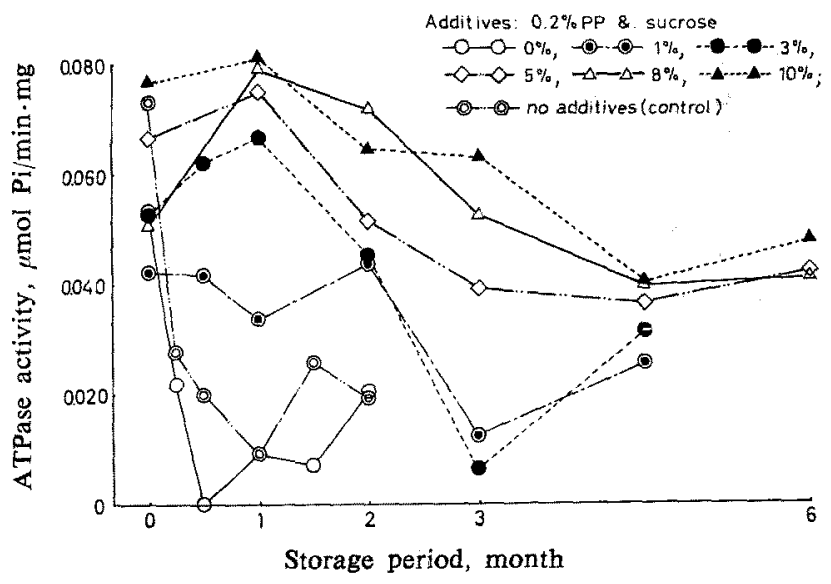

Fig. 4. Effect of sucrose of various concentrations on the changes in ATPase activity. of $0.6 \mathrm{M} \mathrm{KCl}$ soluble protein in lyophilized carp myofibrillar powder during storage at $20^{\circ} \mathrm{C}$.

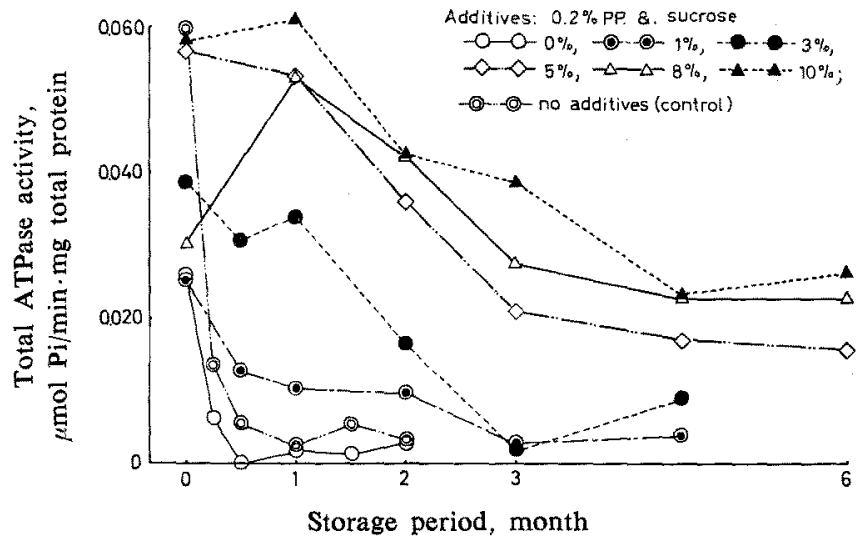

Fig. 5. Effect of sucrose of various concentrations on the changes in total ATPase activity of lyophilized carp myofibrillar powder during storage at $20^{\circ} \mathrm{C}$.

The total ATPase activity of materials seems correlated with the amount and the specific activity of soluble actomyosin which in turn related to kamabokoforming ability. The total ATPase activity is the product of soluble nitrogen content by ATPase activity, expressed as $\mu \mathrm{mol}$ free phosphate per min, per mg total sample protein.

スタロースのタンパク質保護効果については冷湅中で

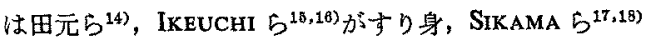
がカタラーゼ, YASUI $b^{18)}$, HaShIMOTO $b^{20)}$ がミオ シソ, 川島 $5^{8)}$, 新井 $5^{21,28), ~ N o G U C H I ~} 5^{28) か ゙ フ ク ト ~}$ ミオシンKついて報告している。凍結郣澡中では上阔 $5^{24)}$ が魚肉, HaShIMOTO $5^{20)}$, YASUI $5^{26)}$ がミオシ ン，花房 ${ }^{26,27}$ がカタラーゼとミオシン，新井ら ${ }^{21) か ゙ フ ク ~}$ トミオシンについて報告してている。小の相違はあるが いずれですスクロースがタンバク筫保護效果を持つこと
が認められている。ただしこれら既往の文献には涷結 藅燥後の貯蔵中の保護效果に関しては何等記戴されてい ない:

ここでタンパク筫が凍結とそれに続く乾燥と眝蔵によ つてどのような変化をするのか，次いでスクロースが保 護効果をどのようにして現すのかについて ${ }^{28-31)}$ 論及し たい。

をだ明らかルされていない部分が多いが，タンが質

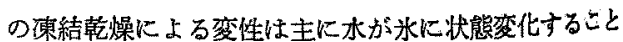


と，本がほほ完全に除かれることによつていよ5。近 年, 办溶液中のタンパク質分子の安定化に扎ける最る重 要な役割を担うるのはそれをとりまく木の棈造と政水結 合であるとされている ${ }^{82-87)}$ 。普通の生理的温度では，非 極珄分子が溶けていると，その囲りに水分子同志が水素 綃合した会合体 (クラスレート，アイスバーグ) を作る 生質を有し ${ }^{382}$ ，温度が低くなると会合体は安定化して增 す。一方タンバク質は天然の状態では規則性のある折 クたたみ棈造 (folding structure) をとるが，その安定 生は共有結合の他に非共有結合によるところが大きい。 水溶液中では非亟性基がそれをとりまく水のクラスレー トの一部を破壊して，水を排除して接近し，眯水結合を 形成することおよびポリペプチド鎖中の水素結合し得 る全ての残基が水素結合を形成することによつて折りた たみ檴造の安定性が保たれていると考えられる。その他 そタンパク質の表面の亟性基の囲りにはいるいろな型の 水和水があり，水和は主に水素結合によつて保たれてい ると考えられる。

蹯水結合は $18^{\circ} \mathrm{C}$ て最も安定であることが知られで日), それより温度が高くとも低くとる不安定となる。従つ て，水が棵ってクラスレートを安定化する時，眯水結合 は破壞される。

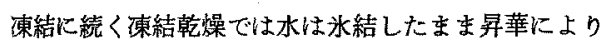
除加，本分0近くにまで達する。その際水和水までも 除かれ，極性基が露出される。るつともこの変化凍結 状態でる水和水がクラスレートに移行するよらな低温で は起こると考えられる。

瑓水結合と水和の破壊は次いで構造上の再配列をもた らし, 変性へ之導くが, 淉結㢹燥直後のまだ非極性基が 移動せず接近して存在する間は, 復水すると蹎水結合 は元炋㞔ると考えられる。これは，非極性基はランダム 状態からでさえ元の折りたたみ構造へと可逆的に移行し らる性質を熱エネルギー的に持つ ご)とによつている。 また水和も元に戻ると考文られるが，その可逆性は瑓水 結合と比べるとずつと小さい(30)。乙かし，全体としては 元の折りたたみ構造に房ると思われる。本実験でも，ス クロース無添加の対照が涷結乾燥直後には高い湘定值を 示していたことからも, これら推察の妥当性が認められ to

眝藏中に水和の破壊された極性基がタンパク翼分子間 に新たな水素結合を形成することにより，凍結乾燥值後 に保持されている折りたた名構造は変化していく。それ はタンペク質分子は溶液中にあるよりあ非水状態にある 洔この変化を受け易く，しかむ，水素結合は供与体と受 容体原子の性質に基づき特徽のある長さと結合角度を維 持する(9)ため，新たな水素結合を形成する時，タンハク 筫分子は形の変化を伴らことになる。括そらく脱水によ

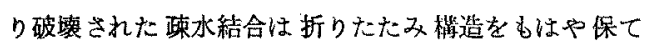
ず，折りたたみ潄造浪部分的にほどてランダム状態に なり，再配列されて $\beta$-型をとることになろ5。分子がは どける際に水和の部位が更に乱されて，復水しても元に 戻らなくなると考えられる。

このよらなタンパク質の変性を防止する上から， NOGUCHI $5^{40,41)}$ はタンパ質保讙物孫は親水性基を二 つ以上持ら，ある立体構造を持つ必要があることをアク トミオシンの倲結実験が指摘し，MORICHI $5^{42-40)}$ も 細菌の凍結乾燥に対する保護物質に関して同様のことを 諗めている。水素結合は特徽のある長さと結合角を持つ という先の記载からす保護物筫がある立体構造を持つこ との必要性が示暖される。

本実験で愉討したスクロースは多数の $\mathrm{OH}$ 基を持つ が，その OH 基により水分子間に介在して凍結に上る クラスレートの安定化を阻止し，またタンパク質分子と 水分子の間に介在して水和の部位支保護し, 凍結乾燥後 の眝蔵中の醂水結合と水和の破壊を防止することにより タンパク質保訬効果を発現すると考えられる。

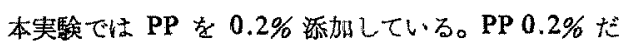
けの添加で怔無添加の対照上りも漧燥直後の測定值が低 く，その後の眝藏中の低下も速く，PP がタンバク質の 変性をむしろ促進することが示された。また罒には示さ なかつたが，筋原㵶維に対するスクロースと PP の住用 効果はほとんど漶められなかつた。無機りン酸塩とタン ヘク質の相互作用に関しては FUKAZAWA ら ${ }^{40)}$, YASUI $5^{47,48)}$ 㘦ピロリン酸, トリポリリン酸, 一キサメタリン 酸と天然のフタトミオシンとの相互作用を詞ベ，ピロリ ン酸だけがフクトミオシンの大きさと形を変える作用を 示し、ソーセージの結着性と保水性を改良するのに有劮 であると記载している。冷湅中てい西谷ら ${ }^{4 \theta\rangle}$, 由元ら がすり身に対する PP の保護効果と，PP と楉の顕著な 併用效果とを琶めているが，川島られは PP の效果を

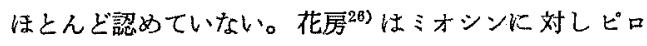
リン酸は保護効果を示さないことを, NoGUCHI $5^{802}$, MATSUMOTO ら51はアクトミオシンに対しトリポリリン 酸ナトリウムが変性抑制効果を示すが，ビロリン酸ナト リウムは示さないことを報告している。谏結乾燥におい ては岡ら ${ }^{62)}$, 上岡ら ${ }^{20}$ は魚肉に対しピロリン酸ナトリウ ム，ならびにそのスクロースとの混液漫濽が吸水率を增 大し，品質を向上さ奴るとを認めている。しかし，花 房 ${ }^{28,27)}$ はピロりン酸ナトリウムがミオシンとカタラーゼ

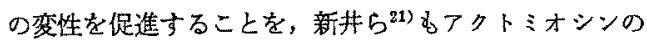
冷凍および揀結教燥に対し PP，ならびに PP とスク口 一スとの併用が好果を示さないことを報告している。こ の上うに既往の文献によつてもりン酸塩の効果に関する 見解は一致していない。更に，リン酸塩の效果において 
はイオン隐度による遮いが考允られることから，PP の 侀用效果についてる一つの央験結果から断定士ることは 灘しい。

$$
\text { 要 䄪 }
$$

1.コイ筇原絨維にポリリン酸㫊 $0.2 \%$ とスクロース $10 \%$ 以下添加 L, 凍結乾燥後, 厚さ $0.1 \mathrm{~mm}$ のポり ×チレン封入し， $20^{\circ} \mathrm{C}$ で詝葴し，スクロースのタ ンパク質保護効果を比較した。

2. 品質判定は $0.6 \mathrm{M} \mathrm{KCl}$ 可溶性窒素量, 粘度, ATPase 活性, および全 ATPase 活性の濯定により行 Dto

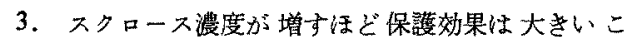
としかし５\% 以上では大差がないことが認められた。

4.ポリリン酚塩 $0.2 \%$ ボけの添加ではタンパク貿の 変性をむしろ促進することが認められた。

本研究の遂行に当り終始ご郎箁なるご指導を賜わつた 東京水産大学教授田中和夫博士に深く感謝いたします。 また，上智大学教授松本重一郎博士，大洋漁業(株)野口 敏博士には有益なご助言を賜わつたこと，ならびに本春 験飞東京水産大学学生片山博視，駒木 勝両君の捥力を 得たことを記し，厚く御礼申し上げます。

\section{文献}

1）松田由美子：日水誌，37，130-134 (1971).

2）松田由美子：日水誌，37，135-139 (1971).

3) 松田由美子: 日水誌, 45, 511-515 (1979).

4) 松田由美子：日水郝，45, 517-521 (1979).

5) Y. Matsuda: in "Proceedings of the XIIIth International Congress of Refrigeration Washington DC 1971", Vol. 3, AVI, Westport, 1973, pp. 749-756.

6)川島孝省・新井健一・紊藤恒行：日水誌，39, 207-214 (1973).

7)川島孝省・新井健一・斎藤恒行：日水誌，39， 525-532 (1973)

8) 川島孝省・大場明子・新井健一：日水䓌，39， 1201-1209 (1973).

9) S.V. Perry: Biochem. J., 51, 495-499 (1952).

10) S. Noguchi and J.J. Matsumoto: Bull. Japan. Soc. Sci. Fish., 36, 1078-1087 (1970).

11) C.H. Fiske and Y. Subbarow: J. Biol. Chem., 66, 375-400 (1925).

12）古川美採・種田雅子・中村康吉 - 春日諴次，吉 川春泰：生化学，24，76-82 (1952).

13）高橉泰常：生化学㴭域に抬ける光電比色法, 各 䄖 2 (関根隐光・笠川泰治・森田茂広・木村徳 次・會富一興槅)，第 2 版，南江堂，東京， 1960 , pp. 8-11.

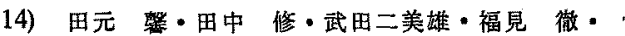
西谷喬助: 北水研却, No. 23，50-60 (1961).
15) T. IkeuchI and W. Simidu: Bull. Japan. Soc. Sci. Fish., 29, 157-160 (1963).

16) T. IkEUChr and W. Simidu: Bull. Japan, Soc. Sci. Fish., 29, 258-262 (1963).

17) K. Shikama and I. Yamazakr: Nature, 190 , 83-84 (1961).

18) K. Shixama: Sci. Rep. Tohoku Univ. Ser. IV (Biol.), 29, 91-106 (1963).

19) T. Yasul, J. Morita, and K. Takahashi: J. Biochem., 60, 303-316 (1966).

20) Y. HAshimoto and T. YAsur: Nature, 211, 194-195 (1966).

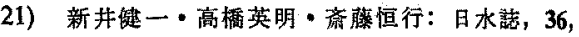
232-236 (1970).

22）新井煡一・高士令二：日水声，39，533-541 (1973).

23) S. Nogucht, K. Oosawa, and J.J. MatsuMoto: Bull. Japan. Soc. Sci. Fish., 42, 7782 (1976).

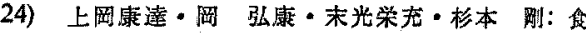
品工誌，13，475-480 (1966).

25) T. Yasur and Y. Hashimoto: J. Food Sci., 31, 293-299 (1966).

26) 花房尚史：低温科学，B27，11-22 (1969).

27) 花房尚史: 低温科学, B 32, 1-8 (1974)。

28)花房尚史：凍結 - 乾爆々緗胞傽害（根井外喜男 絧)，東大出版会，東京，1970, pp. 1-19.

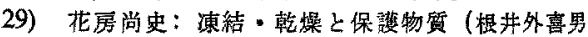
編)，東大出版会，東京，1972，pp. 10-23.

30)花房尚史：食品の水一水分活性と水の举助（日 本水産学会編)，水産学シリーズ 3，恒星社原 生閣，東宗，1973，pp. 9-24,

31) 花房尚史: 椧涷, 48, 713-722 (1973).

32) I.M. KLotz: Science, 128, 815-822 (1958).

33) W. Kauzman: in "Advances in Protein Chemistry" (ed. by C.B. ANFInSEN, M.L. ANSON, K. BAtley, and J.T. Edsall), Vol. 14. Academic Press, New York, 1959, pp. $1-63$.

34）浜口浩三・黑野朝子・後藤幸男：生物物理，1, 176-180 (1961).

35) G. Nemethy and H.A. Scheraga: J. Phys. Chem., 66, 1773-1789 (1962).

36) K. Shikama: Sci. Rep. Tohoku Univ. Ser. IV (Biol.), 31, 67-73 (1965).

37) J.L. Kayanay: Structure and Function in Biological Membranes, Vol. 1, Holden-Day, San Francisco, 1965, pp. 171-248.

38) H.S. Frank and M.W. Evans: J. Chem. Phys., 13, 507-532 (1945)

39) R.H. HASCHEMEYer and A.E.V. HASCHEMEYER: Proteins-A Guide to Study by Physical and Chemical Methods, Wiley, New York, 1973, pp. 109-129.

40) S. Noguchi and J.J. Matsumoto: Bull. Japan. Soc. Sci. Fish., 41, 243-249 (1975).

41) S. Noguchi and J.J. Matsumoto: Bull. Japan. Soc. Sci. Fish., 41, 329-335 (1975).

42) T. MORICHI, R. IRIE, N. YANO, and H. 
Keмво: J. Gen. Appl. Microbiol., 9, 149 161 (1963).

43) T. MORICHI, R. IRIE, N. YANO, and H. Kembo: Agr. Biol. Chem., 29, 61-65 (1965).

44) 森地钽樹: 生細胞の涷結䩐燥 (根井外喜男編). 日本学術掓興会, 東京, 1965 , pp. 38-47.

45) T. MORICHI: in "Proceedings of the First International Conference on Culture Collections" (ed. by $H$. IIzukA and $T$. Hasegawa), Univ. of Tokyo Press, Tokyo, 1970, pp. 351-361.

46) T. FuKazawa, Y. Hashimoto, and $T$. YASUI: J. Food Sci., 26, 550-555 (1961).

[47) T. Yasui, M. Sakanishi, and Y. Hasimoto: J. Agr. Food Chem., 12, 392-399 (1964).
48) T. Yasui, T. Fukazawa, K. Takahashi, M. SAKANishi, and Y. Hashimoto: $J . A g r$. Food Chem., 12, 399-404 (1964).

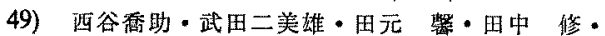
福胃徽・久保正・鳥谷部箩男：北水試月報， 17, 373-384 (1960).

50) S. Noguchi and J.J. Matsumoto: Bull. Japan. Soc. Sci. Fish., 37, 1115-1122 (1971).

51) J.J. Matsumoto and S. NoguchI: in "Proceedings of the XIIIth International Congress of Refrigeration Washington DC 1971". Vol. 3, AVI, Westport, 1973, pp. 237-241,

52) 岡 弘康 -末光栄充・上岡旅橽：愛媛総指報， 2 号，32-35 (1965). 